\title{
Composition and Diversity of Soil Arthropods of Rajegwesi Meru Betiri National Park
}

\author{
Hasan Zayadi ${ }^{*}$, Luchman Hakim², Amin SetyoLeksono²
}

${ }^{1}$ Biology Department, Faculty of Mathematics and Natural Sciences, Islamic University of Malang, Indonesia

${ }^{2}$ Biology Department, Faculty of Mathematics and Natural Sciences, Brawijaya University, Malang, Indonesia

\begin{abstract}
Meru Betiri National Park (MBNP) is one of the nature conservation area that has the potential of flora, fauna, and ecosystems that could develop as a nature-based tourism attraction. The existence of certain indicator species was related to estimation of stress level and disturbance on ecosystem stability for making strategic decisions about the restoration in this area. One of the important indicator species at forest ecosystem were soil arthropods. Aim this research were analyzed composition and diversity of soil arthropods at Rajegwesi, MBNP areas. The methods in this research used pitfall trap, measurement of distribution structure and soil arthropods composition based on the Shannon - Wiener index, Morisita similarity index and Importance Value Index (IVI). The number of families and individuals of soil arthropods found in the coastal area of Rajegwesi consists of 10 order with 21 families (702 individual). The number of individuals of the order Hymenoptera, Coleoptera, Collembola and Araneida was more widely found. Soil arthropods diversity index on each land use indicated that soil arthropod diversity in these areas were moderate. Soil arthropod community of orchards and forest had a similarity of species composition, whereas soil arthropod community of savanna had a similarity of species composition with paddy fields.
\end{abstract}

Keywords: MBNP, Soil Arthropods, Piffall trap, Restoration

\section{INTRODUCTION}

Meru Betiri National Park (MBNP) is natural conservation areas that have potential of flora, fauna, and ecosystems that could develop as a nature-based tourism attraction. MBNP is also protected forest areas that have important value for stabilized the ecosystem and biodiversity.

Considerations that can be used for spatial planning was biodiversity values of species composition in this area [1]. Knowledge about the existence of certain indicator species significantly related to assessing the stress level and disturbance on the ecosystem. Indicator species such as trees, birds, butterflies, and mammals were easily sampled and monitored, also represent a diverse group of biological significance.

However, not all of this showed interrelations with other taxa diversity nor show response to

\footnotetext{
${ }^{*}$ Corresponding author:

Hasan Zayadi

Biology Department, Faculty of Mathematics and Natural

Sciences, Islamic University of Malang, Indonesia

Email: hasanzayadi84@gmail.com
}

ecosystem change [2]. Ones of the important indicator species were soil arthropods, and it was important groups from terrestrial ecosystems [3, 4]. Soil arthropods play a significant role for the function and stability of an ecosystem [5]. A lot of investigations on soil arthropods prove that it was used to evaluate of quality and mana-gement ecosystems and used for the restoration program for damaged ecosystem [6,7]. Disturbance or loss of soil insects can cause loss of function and will affect vegetation in these areas [8].

Soil arthropods directly or indirectly influenced by vegetation above it. Hence, vegetation diversity will also determine soil arthropod diversity beneath it [9]. Some arthropods are very specific to certain habitats; depend on the maximum application for nesting, mating, and food availability. Their preference to microhabitat above investigated by sampling of soil arthropods at different habitat along with mapping the vegetation with remote sensing and GIS to provide the details about soil arthropods distribution, endemism, and pattern of habitat change $[2,10$, 11]. The aims of this research were analyzed 
composition and diversity of soil arthropods at Rajegwesi, MBNP areas.

\section{MATERIALS AND METHODS}

This research conducted in January-April 2012 at the coastal area of Rajegwesi (8032'41.14"S 113055'51'. 960E), these areas are part of Meru Betiri National Park (Figure1).

\section{Distribution structure and composition of soil arthropods measurement}

Transect created on land use which already have been classified; savannah, paddy fields, plantations, and woods. Transect is 100 meters, distance of each plots are 25 meters. In each plot fitted with one trap bottle (pitfall trap) that has been filled with formaldehyde $4 \%$ about $2-5 \mathrm{~cm}$, traps put by digging the soil until surface of bottle equal with soil surface. Installation of bottle traps was done at 07:00 am and collected three days later (until 3x24 hours) [12].

\section{Abiotic Factor Measurement}

Measured abiotic factors are temperature and humidity based on data from Meteorology Clima-tology and Geophysics Department (BMKG) Banyuwangi region on April 2012, light intensity, and soil $\mathrm{pH}$, organic matter compound $(\mathrm{C} / \mathrm{N}$ ratio and organic matter).

Soil diversity at each land use to calculate with Shannon-Wiener index (H'). Composition of soil arthropods analysis conducted by comparing between plots sampling at each different land use. Similarity Composition between two locations analyzed by Morisita index. The parameters used to compare the soil arthropod community structure are importance value index. Variable measured are relative frequency and abundance frequency.

number taxa and abundance individual of each taxa. Another caused was several taxa Collembolans and Formicidae) more dominated than others. Present of Collembolan was widely deter-mined by higher soil organic matter, which cau-sed by past decomposition processes. It also similar for family of Formicidae, This is due to the family of the formicidae (ant) having a manner of living that same with Termitidae (termites) that living for colonies and was made to levels categories [14]. Formicidae reaches 70\% from tropical animal soil population, that it can be found on large amount [15].

\section{RESULTS AND DISCUSSION}

\section{Composition of soil arthropods}

Soil arthropods were found in several categories of land use; savanna, paddy fields, orchards, and forest (Table 1). Sum of taxa and individual of soil arthropods were very various. It is to consist of 10 orders with 21 families (702 individuals). Based on Table 1, sum of individual were order Hymenoptera, Coleopterans,

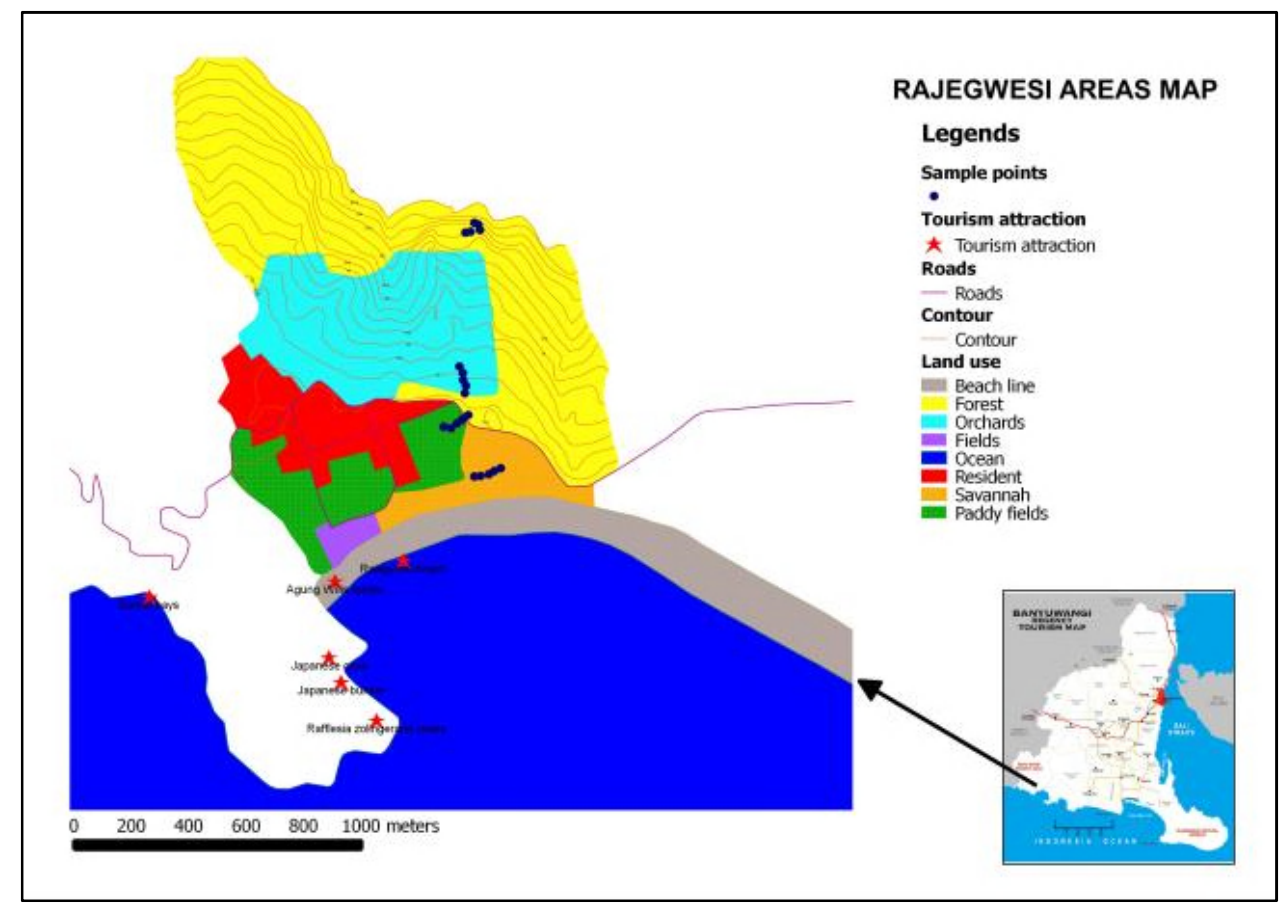

Figure 1. Study area in Rajegwesi, MBNP 
Table 1. Order and individuals abundance of soil arthropods found of Rajegwesi, MBNP areas

\begin{tabular}{|clcc|}
\hline NO & Order & $\sum$ Family & $\sum$ Individual \\
\hline 1 & Hymenoptera & 3 & 283 \\
2 & Coleoptera & 5 & 145 \\
3 & Collembola & 1 & 113 \\
4 & Araneida & 2 & 68 \\
5 & Orthoptera & 2 & 64 \\
6 & Diptera & 3 & 20 \\
7 & Neuroptera & 1 & 4 \\
8 & Lepidoptera & 2 & 2 \\
9 & Homoptera & 1 & 2 \\
10 & Diplopoda & 1 & 1 \\
Total & & 21 & 702 \\
\hline
\end{tabular}

Collembolans and Araneida which were very abundant. It's due to these order arthropods were common soil arthropods that found at ground level [13].

Order of Collembolans and Hymenoptera were very abundant at all land use, because these orders occupying $80 \%$ of the soil arthropod population $[5,9]$. Differences abundance of indviduals and species of soil arthropods was caused by the vegetation diversity, environmental condi-tions, and abundance of litter in these areas. Coleopterans also dominated these areas, caused by the abundant availability of feed.

Soil arthropod diversity at each land use (Table 2) showed that there are differences abundance of taxa and individuals. Forest species abundance was highest with 232 individual and 15 families. Whereas, orchards land use have the lowest species abundance (120 individual and 10 families).
Savanna was dominated by Formicidae and Collembolans. Species in this land use were dominated by Pheidologeton spp. (Hymenoptera: Formicidae) with importance value index 39.56, Aenictus (Hymenoptera: Formicidae), and Dolichoderes (Hymenoptera: Formicidae) 30.96 Entomobrya (Collembola: Entomobryadae) 28.21. Dolichoderes sp. roles as predator of small and weak insect or animal, also roles as decomposer of organic matter [16]. Naturally, ants could be preferred for indicator of environmental condition changes, it also roles to maintain the nutrition cycle and structure of soils. Soil temperatures have average about 32.10C. Ants can be used for habitats indicator status [2].

Dominated at paddy fields family and species were: Pheidologeton spp. (Hymenoptera: Formicidae) with importance value index 49.57, Lycosa (Araneida: Lycosidae) was 25.07, and Locusta migratoria (Orthoptera: Acrididae was 23.35.

Table 2. Richness and diversity index of soil arthropods of Rajegwesi, MBNP areas

\begin{tabular}{|rlcccc|}
\hline No & Areas & Order & $\sum$ Family & $\sum$ Individual & $H^{\prime}$ \\
\hline 1 & Forests & 9 & 15 & 232 & 2.16 \\
2 & Orchard & 6 & 10 & 120 & 2.10 \\
3 & Paddy fields & 7 & 11 & 164 & 2.01 \\
4 & Savannah & 8 & 11 & 186 & 1.89 \\
\hline
\end{tabular}

Table 3. Similarity index value of soil arthropods composition of Rajegwesi, MBNP areas

\begin{tabular}{|ccccc|}
\hline & Savannah & Paddy fields & Orchard & Forests \\
\hline Savannah & 1 & 0.72 & 0.55 & 0.48 \\
Paddy fields & 0.72 & 1 & 0.43 & 0.36 \\
Orchard & 0.55 & 0.43 & 1 & 0.89 \\
Forests & 0.48 & 0.36 & 0.89 & 1 \\
\hline
\end{tabular}




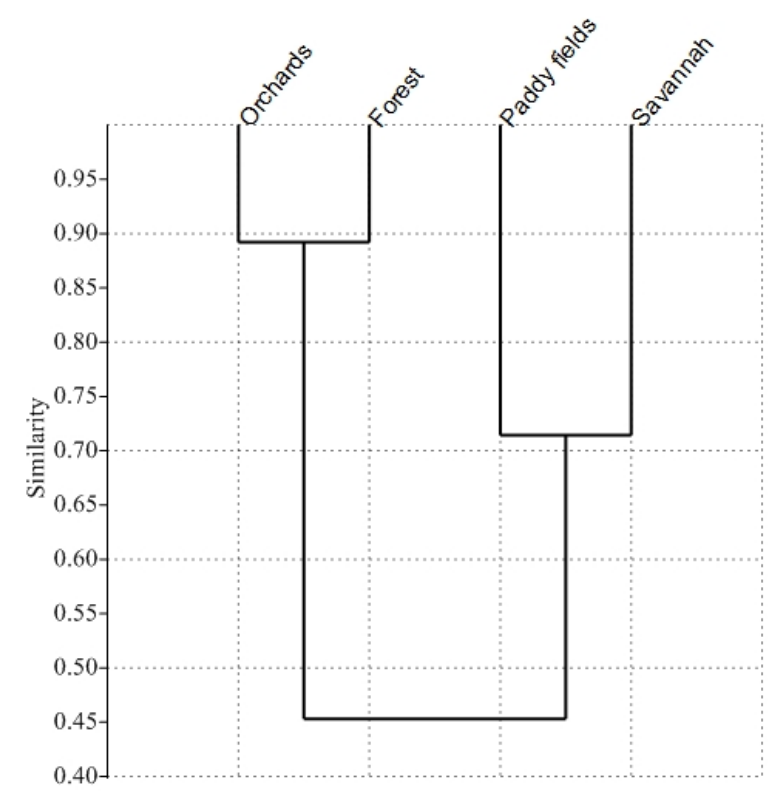

Figure 2. Similarity index of soil arthropods composition on different land use of Rajegwesi, MBNP areas by PASTsoftware.

Table 4. Abiotic factor of Rajegwesi, MBNP areas

\begin{tabular}{|lccccc|}
\hline \multicolumn{1}{|c}{ Areas } & $\begin{array}{c}\text { Organic compounds } \\
(\%)\end{array}$ & Ratio C/N & $\mathrm{pH}$ & $\begin{array}{c}\text { Conductivity } \\
\text { (micro S) }\end{array}$ & $\begin{array}{c}\text { Light intensity } \\
\text { (lux) }\end{array}$ \\
\hline Savannah & 13.50 & 20.26 & 5.89 & 158.92 & 114.36 \\
Paddy fields & 10.72 & 19.44 & 6.22 & 32.06 & 29.15 \\
Orchard & 4.89 & 16.14 & 6.25 & 92.24 & 396.60 \\
Forests & 12.49 & 20.76 & 6.32 & 154.68 & 0.15 \\
Means & 40.40 & 19.15 & 6.17 & 109.47 & 135.06 \\
\hline
\end{tabular}

Dominated family and species at orchards were: Entomobrya (Collembola: Entomobryadae) with importance value index 36.67, Adoretus compressus (Coleoptera: Scarabidae) 35.63, and Aenictus (Hymenoptera: Formicidae) sebesar 25.21. Forest were dominated by Adoretus compressus (Coleoptera: Scarabidae) 37.11, Entomobrya (Collembola: Entomobryadae) 26.21, and Aenictus (Hymenoptera: Formicidae) 21.04.

Result of soil arthropods Similarity index at each land use (Table 3 and Figure 2), showed that orchards and forest have a high similarity index about 0.89 . This caused by before land use change into orchards, this land was forest, and so both land use have an almost similar habitat condition. Savanna and paddy fields have a similarity index about 0.72 . Forest and paddy fields have a lower similarity index about 0.36 then orchards and paddy fields about 0.43 .

The difference of above community structure also affected by abiotic factors such as: temperature, humidity, soil $\mathrm{pH}$, soil conductivity, and light intensity, beside that affected also by con- tent of organic matter and ratio $\mathrm{C} / \mathrm{N}$ (Table 4). Average of temperature of Rajegwesi, MBNP areas was $28.270 \mathrm{C}$ and humidity was $78.9 \%$. This temperature was optimal temperature for organism growth especially for soil arthropods. Average of forest temperature was $23,40 \mathrm{C}$, average of soil temperature was $25,90 \mathrm{C}$, and average of soil $\mathrm{pH}$ was 6,6 [15]. Soil temperature was one of the soil physic factor that determine of the existence and density of soil organism [16].

The soil $\mathrm{pH}$ range of this research categorized as neutral 5.9-6.3. Average in light intensity was 135.06 Lux and average of soil conductivity was 109.47. The range of the soil $\mathrm{pH}$ was common for many organisms, this means soil arthropods can live well at neutral $\mathrm{pH}$ and low acidity.

Average of the soil organic compound and $\mathrm{C} / \mathrm{N}$ ratio were $40.40 \%$ and $19,15 . \mathrm{C} / \mathrm{N}$ ratio showed the process of $\mathrm{N}$ mineralization-immobilization by decomposer microbial. The value of this result showed $\mathrm{C} / \mathrm{N}$ ratio lower than 20 , this prove that $\mathrm{N}$ mineralization occurred. When $\mathrm{C} / \mathrm{N}$ ratio was greater than 30 , it means $\mathrm{N}$ 
immo-bilize, and if value among 20 - 30 showed a ba-lance of both $\mathrm{N}$ mineralization and $\mathrm{N}$ immo-bilization. Higher of $\mathrm{N}$ compound on land use cultivated with horticulture caused by use of ma-nure and inorganic fertilizer ( $\mathrm{N}$ fertilizer). The higher of soil $\mathrm{C} / \mathrm{N}$ ratio caused lower diversity [17]. Decreasing content of soil COrganic depends on land use settings after the forest clearing. Planting on tropic land forest reduce the $\mathrm{C}$ compound about $40 \%$, land use for pasture reduce the content of C-organic about $20 \%$. The higher content of C-Organic soil, leads to higher index of soil aggregate stability [18].

Alteration of land use and its management can reduce the soil productivity through the decreased organic matter and physical properties of the soil. There is a relationship between macrofauna, soil organic matter, soil physical properties, plant growth, and soil erosion [19]. Existence soil organic matter and under vegetation cover can generate better microhabitat condition to support the life of various soil organisms, including macrofauna [20].

\section{CONCLUSIONS}

The number of families and individuals of soil arthropods found in the coastal area of Rajegwesi consists of 10 orders with 21 families (702 individual). The number of individuals of the order Hymenoptera, Coleopterans, Collembolans and Araneida was more widely found. Collembolans and Formicidae were dominant families, and dominated species were Pheidologeton spp. (Hymenoptera: Formicidae). Shannon-Wiener diversity index value was higher than other land use about 2.16, and the lowest was 1.89 at savanna. Soil arthropod community of orchards and forest had a similarity of species composition, whereas soil arthropod community of savanna had a similarity of species composition with paddy fields.

\section{ACKNOWLEDGMENTS}

Author thank to Meru Betiri National Park (MBNP) department which gave permission to the research. Rajegwesi Ecotourism Society (RES) for information and collaboration. Author also thanked to Dr. Bagyo Yanuwiadi and Dr. Serafinah Indriyani, M.Si as the reviewer in this research.

\section{REFERENCES}

1. Lubis HS (2006) Ecotourism planning the development of community-based in the area of tourism tangkahan district langkat north Sumatera. North Sumatera University.

2. Ramachandra TV, Ajay N (2001) Ants Habitat Mapping Using Remote Sensing And Gis. Wetlands. 23600985: 1-17.

3. Marra JL, Edmonds RL (2005) Soil Arthropod Responses to Different Patch Types in a MixedConifer Forest of the Sierra Nevada. Society of American Foresters. 51(3):255-65.

4. Nakamura A, Catterall CP, House APN, Kitching RL, Burwell CJ (2007) The use of ants and other soil and litter arthropods as bio-indicators of the impacts of rainforest clearing and subsequent land use. Journal of Insect Conservation. (2): 177-86.

5. Santos AP, Cabanas E, Pereira A (2007) Abundance and diversity of soil arthropods in olive grove ecosystem (Portugal): Effect of pitfall trap type. European Journal of Soil Biology. 43:77-83.

6. Xiuqin YIN, Bo S, Weihua D, Weidong XIN, Yeqiao W (2010) A review on the eco-geography of soil fauna in China. Journal of Geographical Sciences. 20(3):333-46.

7. Bellocq MI, Smith SM (2003) Convergence in arthropod assemblages with various restoration approaches for Canadian deciduous forests. Journal of Insect Conservation. 2003;7:99-109.

8. Syaufina L, Haneda NF, Buliyansih A (2007) Diversity of Soil Arthropods in Gunung Walat Education Forest. Media Konservasi. XII (2): 57-66.

9. Rahmadi C, Suhardjono YR (2003) The diversity of Soil Arthropods in the forest floor of upper River Area of Central Kalimantan, Katingan. Biology news. 6(4):549-54.

10. Hendrickx F, Maelfait J, Wingerden WVAN, Schweiger O, Speelmans M, Aviron S, et al (2007) How landscape structure, land-use intensity and habitat diversity affect components of total arthropod diversity in. Journal of Applied Ecology. 340-51.

11. Mawdsley JR (2008) Use of simple remote sensing tools to expedite surveys for rare tiger beetles (Insecta: Coleoptera: Cicindelidae). Journal of Insect Conservation. 689-93.

12. Ruslan H (2009) Composition and diversity of insects ground level in habitats forest homogeneous and heterogeneous in central education nature conservation (PPKA bodogol), Sukabumi, West Java. VIS VITALIS. 02(1):4353.

13. Borror DJ, Triplehorn CA, Johnson NF (1996) Introduction of insect study. Seven edit. Yogyakarta: Gadjah Mada University Press.

14. Nurhadi, Widiana R (2010) A composition of arthropods the surface of land in the area of former and the final disposal of waste in subdistrict Rambatan Tanah Datar. Ekotrans Universitas Journal. 10(1):1-11. 
15. Rahmawaty (2004) Study Of Soil Mesofauna In Sibolangit Natural Forest tourism Area. Medan. pp. $1-17$.

16. Riyanto (2007) Density; distribution pattern and the role of ants on plants around environmental residence. Science research journal. 10(2):1-13.

17. Hanafiah AK (2012) Fundamental of soil science. Jakarta: Rajagrafindo Persada.

18. Maftu'ah E, Alwi M, Willis M (2005) Potential of soil macrofauna as bioindicator the quality of peat. BIOSCIENTIAE. 2(1):1-14.

19. Ajidirman (2006) Study of the restoration of the C-Organic soil and its relationship with the physical fertility under cover vegetation of Palm. Jurnal Agronomi. 10(2):81-4.

20. Sugiyarto (2000) The diversity of Soil Macrofauna in different Age Stands of Sengon in Kediri Regency Jatirejo. Biodiversity. 1(2):47-53. 